\title{
Siew New Disease Reports \\ First report of Neofusicoccum parvum causing shoot blight of pomegranate in Northern Greece
}

\author{
S.C. Palavouzis ${ }^{1}$, S. Tzamos $^{1}$, E. Paplomatas ${ }^{1}$ and T. Thomidis ${ }^{2 *}$ \\ ${ }^{1}$ Laboratory of Plant Pathology, Agricultural University of Athens, 75 lera Odos street, 11855 Athens, Greece; ${ }^{2}$ Alexander \\ Technological Education Institute of Thessaloniki, Department of Crop Production, 57400, Sindos Macedonia, Greece
}

*E-mail: thomidis@cp.teithe.gr

Received: 22 Dec 2014. Published: 13 Sep 2015. Keywords: Punica granatum, fungal plant disease

Pomegranate (Punica granatum) is an important crop in Greece. In the spring of 2011, shoots of pomegranate cv. Wonderful wilted and were blighted, taking a distinct dark colour (Fig. 1) in commercial orchards located in Vrodou Katerinis, the Prefecture of Pieria, in northern Greece. Visual inspection showed that this pathogen infected about $2 \%$ of the shoots causing a 5\% yield loss approximately. Black pycnidia were formed on the surface of blighted shoots. Conidia were hyaline, nonseptate, fusiform and measured 15-29 x 5-8 $\mu \mathrm{m}$. Isolations from the lower margins of the cankers were made by plating tissue pieces $(\sim 3 \mathrm{~mm})$ onto potato dextrose agar. The plates were incubated at $23^{\circ} \mathrm{C}$ for five days, and a fastgrowing, mouse-grey coloured fungus was consistently isolated from these diseased stems. Reverse sides of the plates were initially white, and then became dark to olive green.

Genomic DNA (50 ng) was amplified using ITS $4 / 5$ with the following PCR run parameters: an initial preheating for three minutes at $95^{\circ} \mathrm{C}$, followed by 34 cycles of denaturation at $94^{\circ} \mathrm{C}$ for one minute, annealing at $55^{\circ} \mathrm{C}$ for one minute, and extension at $72^{\circ} \mathrm{C}$ for two minutes, with a final extension at $72^{\circ} \mathrm{C}$ for eight minutes. An amplicon of approximately $700 \mathrm{bp}$ was sequenced (GenBank Accession No. KR822222) and compared using a MEGABLAST search for highly similar sequences. Alignment data revealed the highest and most significant homology to Neofusicoccum parvum at $99 \%$ (KJ657701).

Koch's postulates were completed in the laboratory by inoculating 20 segments $(6 \mathrm{~cm}$ in length and $1.5-2 \mathrm{~cm}$ in diameter) of one-year-old woody shoots of pomegranate cv. Wonderful. Using a cork borer, a $7 \mathrm{~mm}$ in diameter wound was created in the middle of each shoot segment by removing the bark and a $6 \mathrm{~mm}$ diameter agar plug bearing mycelia from a 15-day-old culture of $N$. parvum was inserted in the wound. The wound was covered with petroleum jelly and wrapped with adhesive tape to prevent desiccation. Ten control segments were similarly wounded and inoculated with an agar disk without fungal mycelium. All inoculated and noninoculated shoot segments were incubated at $25^{\circ} \mathrm{C}$ in moist chambers, after which the resulting necrosis was recorded. Koch's postulates were satisfied after re-isolating the $N$. parvum from inoculated fruits that developed symptoms similar to those observed on shoots collected from orchards.
Although Botryosphaeria dothidea (syn. Fusicoccum aesculi)) has been previously reported to cause fruit rots (Fu et al., 2007) and shoot blight (Liu et al., 2008) on pomegranate in China, to our knowledge, this is the first report of $N$. parvum associated with shoot blight on pomegranate in Greece. Pathogenicity tests conducted by Mohammadi (2013) showed that the fungus $N$. parvum isolated from grapevine was pathogenic to pomegranate. In Greece, the pathogen has also been associated with fruit rot and shoot blight of peaches (Thomidis et al., 2011) and pistachio (Inderbitzin et al., 2010).

\section{Acknowledgements}

This work was funded by O.P. Competitiveness and Entrepreneurship (EPAN II), ROP Macedonia - Thrace, ROP Crete and Aegean Islands, ROP Thessaly - Mainland Greece - Epirus, ROP Attica.

\section{References}

Fu JN, Liu XH, Cai FD, Kou LP, 2007. Identification of pathogenic fungus causing a decay of stored pomegranate fruits using molecular biology technique. Acta Horticulturae Sinica 34, 877-882.

Inderbitzin P, Bostock MR, Trouillas PF, Michailides JT, 2010. A six locus phylogeny reveals high species diversity in Botryosphaeriaceae from California almond. Mycologia, 102, 1350-1368. http://dx.doi.org/10.3852/10-006

Liu HX, Li XD, Zhu XP, Liu AX, 2008. First report of pomegranate stem scab caused by Botryosphaeria dothidea in China. Plant Pathology 58, 400 . http://dx.doi.org/10.1111/j.1365-3059.2008.01962.x

Mohammadi H, 2013. Evaluation of susceptibility of some woody trees and grapevine cultivars to Neofusicoccum parvum and Diplodia seriata associated with grapevine decline in Iran. Iranian Journal of Plant Pathology 48, 211-223.

Thomidis T, Michailides JT, Exadaktylou E, 2011. Neofusicoccum parvum associated with fruit rot and shoot blight of peaches in Greece. European Journal of Plant Pathology 131, 661-668.

http://dx.doi.org/10.1007/s10658-011-9840-0

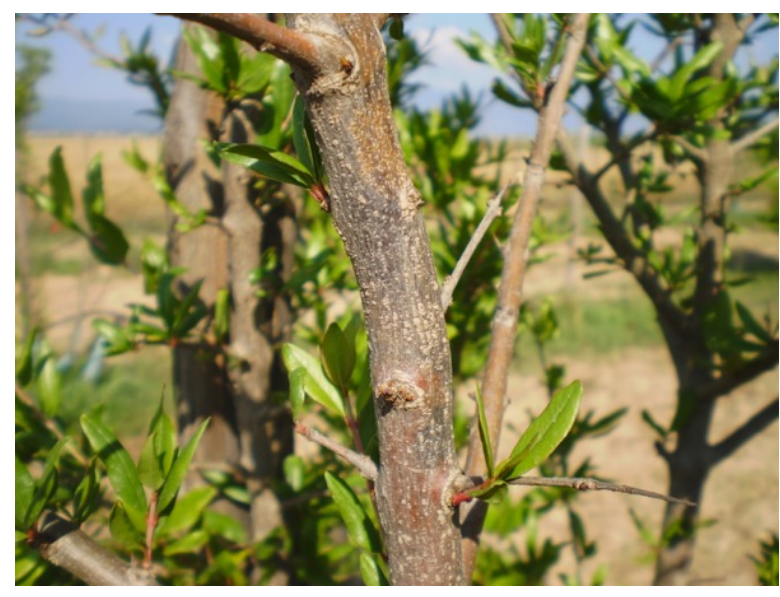

Figure 1

To cite this report: Palavouzis SC, Tzamos S, Paplomatas E, Thomidis T, 2015. First report of Neofusicoccum parvum causing shoot blight of pomegranate in Northern Greece. New Disease Reports 32, 10. http://dx.doi.org/10.5197/j.2044-0588.2015.032.010

(c) 2015 The Authors

This report was published on-line at www.ndrs.org.uk where high quality versions of the figures can be found. 